\title{
Economic valuation of paddy fields: Employment services providers for farmers
}

\author{
Ani Fitriyah ${ }^{1}$ and Bambang Yudi Ariadi1,* \\ ${ }^{1}$ University of Muhammadiyah Malang, Indonesia \\ *Corresponding author: bambang_y@umm.ac.id
}

\author{
KEYWORDS \\ Economic Valuation \\ Paddy Fields \\ Employment \\ Pasuruan \\ SUBMITTED 2 Dec 2020 \\ REVISED 14 Dec 2021 \\ ACCEPTED 4 Jan 2021
}

\begin{abstract}
Agricultural land conversion (ALC) is economically profitable, but what the community does not pay attention to is the losses caused by the ALC. Economic valuation is one way to calculate the multifunctionality of paddy fields that have overall economic value, including the production function, provider of environmental products/services and socio-culture. This study aims at determining the economic value of paddy fields as employment services providers for farmers. The analytical method employed was economic valuation. Research result: It shows that the conversion of paddy fields in Pasuruan Regency in 2014-2019 is quite high, averaging 777.7 Ha per year. The economic value of rice fields as an employment services provider in 2019 is IDR 1,922,772,319,000. This value tends to decline due to land conversion since 2014 .
\end{abstract}

\section{INTRODUCTION}

Based on research conducted by PISA, it is stated that the ability of Indonesian children in mathematics and science is still very low (Kurniawan et al., 2018; Rawani et al., 2019; Zain \& Azwar, 2018). PISA is an international survey initiated by the OECD (Organization for Economic Co-operation and Development) to measure the cognitive skills of students in various countries (Pratiwi, 2019). Students' ability to understanding, communication, connection, problem-solving, and mathematics reasoning is still very low (Bernard \& Rohaeti, 2016; Fatah et al., 2016; Hendriana et al., 2017; Kadir et al., 2017; Sumarmo et al., 2018). The teacher is the heart of implementing learning to improve the quality of education. However, there are many obstacles faced by teachers, one of which is increasing student interest in learning mathematics (Anwar et al., 2019). Students' interest in learning mathematics has decreased from year to year (Davadas \& Lay, 2018; Tee et al., 2020). One of the factors that can affect mathematics learning achievement is student interest and students' positive attitude towards mathematics (Azmidar et al., 2017; Yeh et al., 2019).

Professional teachers as a product of reform in education, must have higher educational qualifications and be able to innovate in teaching and learning (Risdiyanti \& Prahmana, 2020). Many schools have complete facilities, but teachers still use conventional learning, even though one of the factors that can increase student interest in learning is the use of learning media (Anwar et al., 2019). This is due to the lack of teacher skills and limited time in making innovative and interactive learning media (Subandi et al., 2018). Innovative learning is better than conventional learning because it can significantly improve students' abilities (Shahrill et al., 2018).
Learning media is a tool that plays an important role in the teaching and learning process both formal and non-formal (Amalia, 2018). Media is also a supporting aspect of student achievement in the learning process which includes cognitive, affective, and psychomotor aspects (Lalian, 2018). Meanwhile, mathematics learning media is a tool in delivering material related to everyday life to better understand the use of mathematics (Rohaeti et al., 2019). Teachers who can design mathematics learning into real-life using learning media will be able to improve student learning outcomes (Masniladevi et al., 2017). Learning outcomes are the result of the interaction between learning and teaching (Sulasteri et al., 2018).

One of the interactive media that can be used by teachers is e-learning. Currently, the use of e-learning platforms is increasing thanks to developments in information and communication technology (Alhawiti \& Abdelhamid, 2017; Fernández et al., 2017). Based on the above conditions, the researcher will research the development of e-learning based on moodle as a medium forIndonesia is a country whose staple food is rice, so rice becomes its strategic commodity. In 2018, Indonesia experienced a rice surplus of 4.37 million tons, but it decreased to 1.53 million tons in 2019. The decrease in the amount of rice production caused by the decrease of rice field area is on account of the conversion of the rice fields to non-rice fields. Although there was an increase in the area of rice fields resulting from the conversion of swamps and moorlands, the wide of areas was less than the conversion of rice fields to nonrice fields.

The conversion of rice fields to non-rice fields is inevitable because of the high number of people requiring land for housing and road infrastructure. Apart from that, it 
is also caused by the construction and the expansion of factories in strategically located rice fields, tourism (Patiung, 2017), hotels construction, restaurants, hospitals and others.

Economically, the conversion of rice fields provides short-term benefits because the value of rice fields is lower than land used for non-agriculture. The community does not realize that the conversion also causes negative effects on various functions of rice fields (multi-function rice fields) in the form of losses due to loss of environmental and socio-cultural functions. The social function of rice fields as public goods can be enjoyed by many people without having to pay and possesses a tangible economic value that is considerably greater than the conventional calculation of economic value by contributing to the economy, social, culture and the environment for the community (Mamondol, 2017). The conversion of rice fields is not only a problem in agriculture but also a problem in the economic and environmental fields (Patiung, 2017)

The function of rice fields consists of production functions, environmental functions and social functions. Environmental functions are divided into physical functions (preventing floods, conservation of slopes and rice terraces) and chemical functions (maintaining soil nutrients, natural nitrogen supply and water purification) (Damayanti, 2019). Meanwhile, the social functions of rice field cultivation consist of cultural heritage, scientific and educational value, resilience, food security and quality, housing and rural economic activities, providers of employment (sources of income), recreation areas, preservation of rural culture.

The ongoing conversion of productive rice fields to non-rice fields has led to increased poverty, unemployment and urbanization, reduced food (especially rice) security stability, and reduced environmental quality (Patiung, 2017). The conversion of rice fields causes a decrease in the rice fields area affecting the function of rice fields as an employment service provider for farmers. With the decrease in the rice fields area, the demand for the labor for rice field decreases, while the amount of labor force in Indonesia is increasing every year.

The labor forces are those who are in the working age population (aged 15-64 years old). (Sayifullah \& Emmalian, 2018) Moreover, the labor forces are those who are employed or who are willing to work but they have been unable to get a job (unemployed). In addition, those who have jobs but temporarily do not work are considered as the labor forces as well (Sayifullah \& Emmalian, 2018).

In Indonesia, labor absorption in the agricultural sector ranks the second largest, namely $34.6 \%$ (Wiyanti, 2018) to $40 \%$ (the average in 2005-2015) of the total workforce, while the rest work in the non-agricultural sector (Widyawati, 2017). The agricultural sector serves as the basis or foundation for economic development because it carry out a extremely significant role in the Indonesian economy (Dewi et al., 2016). It requires the limitation of the conversion rate on the agricultural land by calculating the economic value of rice fields as an employment service provider for farmers using the economic valuation method of rice fields, learning mathematics to improve student learning outcomes on integral material. So this research aims to develop e-learning based on moodle to improve student learning outcomes in mathematics learning.

\section{METHOD}

The research was conducted in Pasuruan Regency, East Java Province, in October-November 2020, with the following considerations: 1) The land conversion in Pasuruan Regency is moderately high; 2) The number of workers in the agricultural sector is quite a lot as many as 218,608 people (BPS Jatim), whom their age is above the productive age.

\subsection{Data Type and Source}

The data used is primary and secondary data. Primary data were obtained through interviews with purposive sampling, and secondary data were obtained from data available at the Statistics Indonesia (BPS; Badan Pusat Statistik) and the Ministry of Agriculture, as well as other supporting data.

\subsection{Economic Valuation Method}

The economic valuation method used is the Replacement Cost Method (RCM). The evaluation of lowland environmental services uses the Economic Value of Employment Service Providers (EVESP) (in Bahasa Indonesia, NEPLK; Nilai Ekonomi Penyedia Lapangan Kerja). The average value calculation of agricultural land as an employment service providers using a modified formulation of Hidayat et al. (2018) and Mamondol (2017).

$$
\begin{gathered}
\text { EVESP }(\text { NEPLK) }=\text { Ti } \times \text { Wi x IPi x Li } \\
\text { Where: } \\
\begin{array}{c}
\mathrm{Ti}=\text { The need for rice farming labor (MW [Male's } \\
\text { Workday]/ha) } \\
\text { Wi }=\text { Labor Wages (IDR/MW) } \\
\text { IPi }=\text { Cropping index (\%/year) } \\
\text { Li }=\text { Rice field area in land units (ha) }
\end{array}
\end{gathered}
$$

\section{RESULTS AND DISCUSSION}

There is a decline in rice fields with a total of $4,663.63$ hectares or 777.7 hectares per year in five-year period from 2014 - 2019 in Pasuruan Regency. The land conversion rate is influenced by: the number of households, the economic growth, and the number of farmers. A significant increase in the population (Adrianto et al., 2017) requires housing and infrastructure, new opening and expansion of factories built on strategically located fertile agricultural land, building offices, hotels and others. The rice fields conversion will be permanent, so that it cannot be used again as rice fields for the effort to increase production (Hidayat et al., 2018). The rice fields conversion in Pasuruan Regency is shown by the decrease in rice fields area because they are shifted into to non-rice fields, as shown in Figure 1

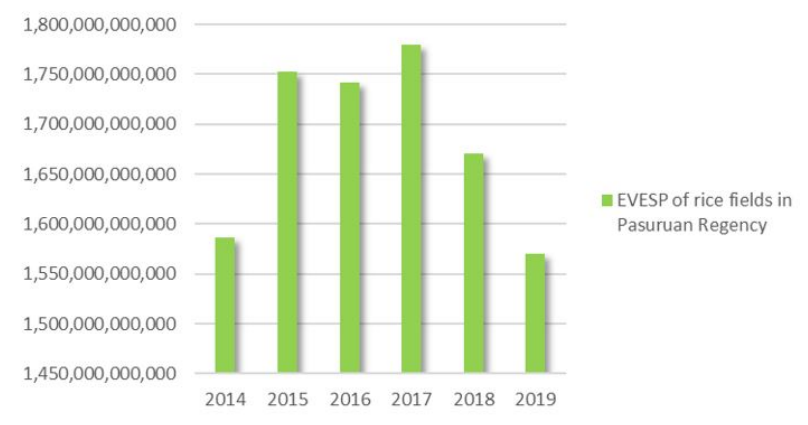

FIGURE 1. Economic Value of Employment Services Providers. 
TABLE 1. The need for rice farming labor per season in Pasuruan Regency.

\begin{tabular}{llc}
\hline Sources and Types of Labor & Unit & Total \\
\hline Male Labor Force (MLF) & $\begin{array}{l}\text { MW (Male's Work- } \\
\text { day)/Ha/Season } \\
\text { HKW (female's work- } \\
\text { day)/Ha/Season }\end{array}$ & 24 \\
Female Labor Force (FLF) & $\begin{array}{l}\text { MW (Male's Work- } \\
\text { day)/Ha/Season }\end{array}$ & 133.8 \\
$\begin{array}{l}\text { Total of Male Equivalent Labor Force } \\
\text { (TMELF) }\end{array}$ & 12.6 \\
$\begin{array}{l}\text { Proportion of Male Equivalent Fam- } \\
\text { ily Labor Force (PMEFaLF) } \\
\text { the proportion of the Wages of Fe- } \\
\text { male Labor Force to the Wages of } \\
\text { Male Labor Force }\end{array}$ & & 70 \\
\hline
\end{tabular}

Source: Primary Data (Processed), 2020.

In economic valuation, rice fields serve a function as employment service providers, which is by providing employment for on-farm, off-farm and out-of-farm trading and distribution activities. The increase in the high number of the labor forces every year is not balanced with the availability of non-agricultural employment which will result in high unemployment. In addition, many of the productive age population have been inactivated (get fired) by factories requiring jobs in agriculture. Therefore, agricultural land, especially rice fields, must be maintained to provide employment for farmers. Jobs in agriculture can accommodate all ages and workers who do not acquire exceptional skills.

The analysis of employment in agriculture is stated by the amount of labor disbursement. The flow of labor represents the amount of effective labor used in a farming activity. The allocation of labor in rice farming is specific; the allocation of male labor is related to soil processing, irrigation, spraying and transportation, while women are related to planting, weeding, and harvesting activities (Hidayat et al., 2018). The results of the calculation of rice cultivation labor requirements are shown in Table 1.

The need for rice cultivation labor absorbs $82.02 \%$ of MLF (male labor force) and $17.02 \%$ of $24 \mathrm{FLF} / \mathrm{ha} /$ season (female labor force). In addition to employing paid labor, rice cultivation activities also use unpaid family labor. The results showed that the activities carried out by the family were $12.96 \%$. In general, the wages received by male labor forces are IDR 50,000 and female labor forces amounting to labor forces IDR 35,000. The wages of female labor forces are $30 \%$ lower than the wages of male labor forces.

The amount of labor force needed for rice cultivation in rice fields per ha is the same every year, with an Index per Plant (IP) of 2.56 (in 2019), the labor force requirement is $299.52 \mathrm{MW} / \mathrm{ha} /$ year and $61.44 \mathrm{FW} / \mathrm{ha} /$ year or equivalent $342.52 \mathrm{MW} / \mathrm{ha} /$ year. If the working day of the permanent worker is 260 days/year, then the work opportunity for 1 hectare of rice field in 2019 is 1.32 people.

Based on the calculation of the conversion of rice fields in Pasuruan Regency, lost employment will result in unemployment in rural areas as many as 1,027 people per year which will trigger a wave of urbanization if there is no absorption of the labor force by other sectors around rural areas. For the community, especially the labor forces in rural areas, the loss of job opportunities due to the conversion of rice fields means that they do not receive wages (Hidayat et al., 2018).

Based on the prevailing wage rates, the potential wages lost due to the conversion of rice fields can be calculated using equation (1). The economic value of lost employment opportunities in agriculture as an employment service provider four farmer per year is IDR 13,318,890,200 or an average of IDR 17,126,000 /ha/year. From this calculation, the conversion of agricultural land has a big impact on the loss of job opportunities requiring serious attention.

Figure 1 shows the economic value of rice fields as an employment service provider contributing significantly to job availability. With the decrease in rice fields area, the EVESP is also getting lower. Therefore, a government policy is required through a policy of sustainable food agriculture (in Bahasa Indonesia, LP2B; Lahan Pertanian Pangan Berkelanjutan) by providing incentives or providing Willingness to Accept (WTA) that farmers deserve because the land they cultivate or own is included in LP2B. The provision of WTA in the form of incentives can be a preventive effort by the government to reduce the rate of conversion of agricultural land functions. The government must pay attention to the improvement and the update of agricultural technology, so that farmers are expected to survive with maximum benefits (Adrianto et al., 2017).

\section{CONCLUSION}

The conversion of paddy fields in Pasuruan Regency is relatively high, with an average of 777.7 hectares per year. The economic value of paddy fields as an employment services provider is IDR $1,922,772,319,000$. This value tends to decline due to land conversion since 2014.

\section{REFERENCES}

Adrianto, D. W., Hasyim, A. W., Dinanti, D., Dwi, J., \& Sandy, H. (2017). Valuasi Sumber Daya Lahan di Pinggiran Kota

TABLE 2. The need for rice farming labor per year in Pasuruan Regency .

\begin{tabular}{|c|c|c|c|}
\hline Statements & Unit & Formula & Score \\
\hline \multicolumn{4}{|l|}{ The need for labor forces } \\
\hline MLF & $\mathrm{MW} / \mathrm{Ha} /$ Season & The need for male labor forces per season X IPi & 299.52 \\
\hline FLF & $\mathrm{FW} / \mathrm{Ha} /$ Season & The need for female labor forces per season X IPi & 61.44 \\
\hline PMEFaLF & $\mathrm{MW} / \mathrm{Ha} /$ Season & The need for labor forces per season X IPi & 342.52 \\
\hline Average of land conversion/year & $\mathrm{Ha} /$ Year & The amount of land reduction / $\mathrm{i}$ & 777.7 \\
\hline The value of lost employment opportunities / year & IDR & $\operatorname{EVESP}(\mathrm{NEPLK})=\mathrm{Ti} \times \mathrm{Wi} \times \mathrm{IPi} \times \mathrm{Li}$ & $13,318,890,200$ \\
\hline Value of lost employment opportunities / ha & IDR & $\operatorname{EVESP}(N E P L K)=T i \times$ Wi $\times I P i$ & $17,126,000$ \\
\hline
\end{tabular}

Source: Primary Data (Processed), 2020. 
Malang ( Studi Kasus: Wilayah Pinggiran Kota Malang, Kelurahan Tunggulwulung Kecamatan.

Damayanti, R. P. (2019). Valuasi Ekonomi Multifungsi Lahan Sawah untuk Kebijakan Agribisnis. Tesis, 1-44. https://doi.org/10.1017/CBO9781107415324.004

Dewi, R. F., Prihanto, P. H., \& Edy, J. K. (2016). Analisis penyerapan tenaga kerja pada sektor pertanian di Kabupaten Tanjung Jabung Barat. Ekonomi Sumberdaya Dan Lingkungan, 5(1), 19-25.

Hidayat, Y., Ismail, A., \& Ekayani, M. (2018). Dampak Konversi Lahan Pertanian Terhadap Ekonomi Rumah Tangga Petani Padi (Studi Kasus Kecamatan Kertajati Kabupaten Majalengka Jawa Barat). Jurnal Pengkajian Dan Pengembangan Teknologi Pertanian, 20(2), 171. https://doi.org/10.21082/jpptp.v20n2.2017.p171-182

Mamondol, M. R. (2017). Multifungsi pertanian padi sawah di Kabupaten Poso. Jurnal ENVIRA Volume 2 Nomor 1 Juni 2017, 2, 1-11.

Patiung, M. (2017). Trategi mempertahankan lahan sawah produktif dalam mewujudkan ketahanan pangan dan melestarikan lingkungan hidup di Kabupaten Tuban, Provinsi Jawa Timur, Indonesia. Prosiding Seminar $\mathrm{Na}-$ sional, 33-43.

Sayifullah, S., \& Emmalian, E. (2018). Pengaruh Tenaga Kerja Sektor Pertanian Dan Pengeluaran Pemerintah Sektor Pertanian Terhadap Produk Domestik Bruto Sektor Pertanian Di Indonesia. Jurnal Ekonomi-Qu, 8(1). https://doi.org/10.35448/jequ.v8i1.4962

Widyawati, R. F. (2017). Jurnal Economia, Volume 13, Nomor 1, April 2017 Analisis keterkaitan sektor pertanian dan pengaruhnya terhadap perekonomian Indonesia (analisis input ouput). Jurnal Economia, 13(April), 14-27.

Wiyanti, D. P. (2018). Prediksi KebutuhanPangan Pokok Padi dan Jagung Terhadap Perubahan Jumlah Penduduk Tahun 2018-2038 di Kabupaten Pasuruan. 1-8. 